\title{
BIRDS OF KOLE WETLANDS, THRISSUR, KERALA
}

\author{
C. Sivaperuman and E.A. Jayson* \\ Division of Wildlife Biology, Kerala Forest Research Institute, Peechi, Kerala 680653, India. \\ * Corresponding Author \\ E-mail: jayson@kfri.org
}

\begin{abstract}
Bird community of Kole wetlands in Thrissur District, Kerala State was studied during November 1998 to December 1999. The methodology followed was mainly observations using spotting scope. A total of 167 species of birds, belonging to 16 orders and 39 families were recorded from the area during the period. Among them, 53 species of birds were winter visitors. Highest number of birds was recorded in the month of January and the lowest was observed in June. Little Egret, Cattle Egret, Little Cormorant, Pond Heron, Median Egret and Whiskered Tern were the most abundant resident and local migrant species found in the Kole wetlands. The importance of this wetland area as the "stepping stone" for the trans-continental migrants is discussed.
\end{abstract}

\section{Keywords}

Birds, Kole wetland, conservation probelms, inventory

\section{Introduction}

Wetlands are areas of marsh, ponds, swamps, whether natural or artificial, permanent or temporary, with water that is static or flowing, fresh, brackish or salty, including areas of marine water, the depth of which at low tide does not exceeded six meters (Anon, 1971). Wetlands are extremely important areas throughout the world for wildlife protection, recreation, sediment control, flood prevention, educational and scientific uses. Wetlands play an important role in the socio-economic stability of local community activities such as fisheries (fresh and saltwater).

Waterbirds are an important component of most of the wetland ecosystems, as they occupy several trophic levels in the food web of wetland nutrient cycles. Waterbirds are broadly defined as "birds ecologically dependent on wetlands" and include

Received 9 May 2000 Accepted 2 September 2000 recognized groups popularly known as wildfowl, waterfowl, shore birds and waders. Among the wetlands in Kerala, Kole wetland in Thrissur District occupies an important position (Anon, 1996). According to Perennou (1990) out of the nine resident endangered waterfowl, four were seen in Kole wetlands. Jairaj and Kumar (1990) reported Eurasian Spoonbill (Platalea leucorodia) from Kole wetlands. Two short term surveys of one week duration employing volunteer bird watchers were conducted to list the birds of Kole wetlands during the winter months of 1992 and 1993 (Anon, 1992; 1993). Details of these surveys and earlier census data were compared and published by Nameer (1993). Ravindran (1993; 1999) reported the occurrence of Glossy Ibis (Plegadis falcinellus) and Whitenecked Stork (Ciconia episcopus) respectively from this area. Ravindran (1995) highlighted the importance of conserving wetland birds in the Kole wetlands in another publication. Santharam (1995) reported Plain Sand Martin (Riparia paludicola) from this area. Similarly, Jayson (2000) reported the occurrence of Black Stork (Ciconia nigra) and Sivaperuman and Jayson (in press, b) recorded the presence of Northern Shoveller (Anas clypeata) here. A rare incidence of Blackshouldered Kite (Elanus caeruleus) preying on Wood Sandpiper (Tring a glareola) was also recorded by Sivaperuman and Jayson (in press, a). The importance of conserving the Kole lands of Thrissur was also discussed by Jayson and Sivaperuman (1999).

\section{Study area}

Wetlands in Kerala come under Central Asian-Indian Flyway (Anon, 1996). Kole wetland is one such area with much importance. The name "Kole" refers to the peculiar type of cultivation carried out from December to May and this Malayalam word indicates bumper yield of high returns in case floods do not damage the crops (Johnkutty \& Venugopal, 1993). A major portion of the area here is flat and it remains submerged for about six months in a year, during June to November. These lands were formerly shallow lagoons, which gradually got silted up. Two rivers mainly bring the floodwaters into the area, namely Kechery and Karuvannur, which finally empty into the Arabian Sea. The Kole wetlands cover an area of 11,000 ha. spread over Thrissur 
and Malappuram Districts, extending from the northern banks of Chalakudy River to the southern banks of Bharathapuzha River in the North. The area lies between $10^{\circ} 20^{\prime}$ and $10^{\circ} 40^{\prime} \mathrm{N}$ latitudes and 75 $58^{\prime}$ and $76^{\circ} 11^{\prime} \mathrm{E}$ longitudes. The wetland is a lowlying tract, located $0.5 \mathrm{~m}$. to $1 \mathrm{~m}$. below mean sea level. This paper forms part of a major ecological study being undertaken by us to investigate the community parameters of birds, food and feeding and the damage caused by birds to paddy cultivation.

\section{Methods}

The method of total count was employed to census the bird population. In this method representative blocks were identified and the birds in the blocks were counted using a spotting scope (10x - 45x) or binocular (7 X 50). Birds were identified using physical features with the help of field guides and reference books (Ali, 1969; Woodcock, 1979; Ali \& Ripley, 1983; Neelakantan et al., 1993; Grimmett et al., 1998; Daniels, 1998). Birds were identified up to species level and details like the number of birds and the habitat were also recorded. The census was conducted between 0700 hours to 1000 hours and on an average covered 15 days in a month.

Representative areas like Enamavu, Kanjany, Arimpur, Mulloorkayal, Adat, Alapatt and Pullu were censused in each month. Along with this other areas were also surveyed. The census was carried out during November 1998 to December 1999 and following assumptions were used to derive the abundance of each species (Nameer et al., 2000).

$\mathrm{A}=$ Abundant (found in all suitable habitats and seen in all the habitats, every visit)

$\mathrm{C}=$ Common (found in all suitable habitats and seen in all the habitats, most of the visits)

$\mathrm{U}=$ Uncommon (seen in specific habitat on a few visits)

$\mathrm{O}=$ Occasional (seen in suitable habitat once or twice).

Status of species is classified into Resident (R), Local movement (LM) and Migrant (M). Winter visitors from Central Asian Countries are included in migrants, where as winter visitors from other parts of the Indian sub-continent is included in the category of local movement.

\section{Results}

A total of 167 species of birds, belonging to 16 orders and 39 families were recorded from the Kole wetlands (Table 1). Among them 81 species are wetland birds. During the study, 53 species of winter visitors were also recorded. Of these migratory birds, nine were ducks, 31 waders, three gulls and two terns. Kole wetland is an abode of many passerine species also. Highest number of birds was recorded during the month of January and lowest in June. Little Egret, Cattle Egret, Little Cormorant, Pond Heron, Median Egret and Whiskered Tern were the most abundant species in the Kole wetlands.

Among the species recorded, Spot-billed Pelican (Pelecanus philippensis) is a species included in the Red Data Book and another species Rufous Babbler (Turdoides subrufus) is endemic to Western Ghats. Neelakantan, et al. (1993) reported 19 orders, 65 families and 475 species of birds as occurring in Kerala.

\section{Conservation problems}

Many factors, which threaten the Kole wetland ecosystem and in turn the bird population were identified during the study. Among them the prominent were poaching of birds, heavy use of pesticides, and unregulated fishing from the canals laid in Kole land to drain excess water. Pesticides and herbicides of 15 different brands were used in the paddy fields for the protection of paddy. Birds were hunted using shotgun and air gun and many such incidents were recorded. Another method used for killing birds was by anesthetising them using the insecticide Furadan, which was fed to birds, by concealing it in small dead fish. Uncontrolled fishing depletes the food source of wetland birds. Small sized gill nets are used for fishing which results in the removal of even small sized fishes, indirectly affecting the availability of food for birds. As suggested by many workers in the earlier reports, if Kole wetlands are declared as a Ramsar site, birds will be protected more seriously.

\section{Discussion and Conclusions}

The number of species recorded from the Kole wetlands shows high species-richness, which is comparable to other wetlands in Kerala (Jayson \& Easa, 2000). Among the species recorded, 53 were winter visitors. As this wetland is coming under 'Central Asian - Indian Flyway', protection of winter visitors need highest priority. As reported earlier from the Western Ghats, highest number of birds were recorded during the months of winter and there was a reduction in population size during the monsoon (Daniels, 1998). As Kole wetlands are serving as "stepping stone" for the trans-continental migrants, urgent measures are needed to protect this wetland ecosystem for the conservation of migratory birds.

\section{Acknowledgements}

We are thankful for the financial assistance from the Kerala Forest Department (Wildlife Wing). Dr. J.K. Sharma, Director, KFRI has shown great interest in this project. We thank Dr. K.K.N. Nair and Dr. P.S. Easa for suggestions.

\section{References}

Ali, S. (1969). The Birds of Kerala. Oxford University Press, Bombay, $444 \mathrm{pp}$.

Ali, S. and S.D. Ripley (1983). A Pictorial Guide to the Birds of the Indian sub-continent. Oxford University Press, Mumbai, 177 pp.

Anon (1971). Ramsar Convention. The Final Act of the International Conference on the Conservation of Wetlands and Waterfowl. IUCN Bulletin 2, Special supplement pp. 1-4.

Anon (1992). Birds of Kole wetlands: A survey report I. Nature Education Society Trichur (NEST) in collaboration with Kerala Forest Research Institute and Kerala Forest Department, 16 pp. (Draft Unpublished).

Anon (1993). Birds of Kole wetlands: A Survey Report II. Nature Education Society Trichur (NEST), in collaboration with Kerala Forest 


\begin{tabular}{|c|c|c|c|c|c|c|c|c|}
\hline$\#$ & Common Name & Scientific Name & Abund. & Status & Common Name & Scientific Name & Abund. & Status \\
\hline \multicolumn{5}{|c|}{ Podicipedidae } & \multicolumn{4}{|l|}{ Dendrocygnidae } \\
\hline 1. & Little Grebe & Trachybaptus ruficollis & C & $\mathrm{R}$ & 27. Lesser Whistling Duck & Dendrocygnajavanica & C & $\mathrm{R}$ \\
\hline \multicolumn{5}{|c|}{ Pelecanidae } & \multicolumn{4}{|l|}{ Anatidae } \\
\hline 2. & Spot-billed Pelican & Pelecanus philippensis & 0 & $\mathrm{R}$ & 28. Northern Pintail & Anas acuta & $A$ & M \\
\hline & & & & & 29. Northern Shoveller & Anas clypeata & C & M \\
\hline \multicolumn{2}{|c|}{ Sulidae } & & & & 30. Common Teal & Anas crecca & $U$ & M \\
\hline \multirow[t]{3}{*}{3.} & Masked Booby & Sula dactylatra & 0 & M & 31. Spot-billed Duck & Anas poecilorhyncha & C & LM \\
\hline & & & & & 32. Garganey & Anasquerquedula & C & $\mathrm{M}$ \\
\hline & Phalacrocoracidae & & & & 33. Gadwall & Anas strepera & C & M \\
\hline 4. & Great Cormorant & Phalacrocorax carbo & C & LM & 34. Ferruginous Pochard & Aythya nyroca & C & M \\
\hline 5. & Indian Cormorant & Phalacrocorax fuscicollis & 0 & LM & 35. Cotton Pygmy Goose & Nettapus coromandelianus & C & LM \\
\hline \multirow[t]{2}{*}{6.} & Little Cormorant & Phalacrocorax niger & $A$ & $\mathrm{R}$ & & & & \\
\hline & & & & & Accipitridae & & & \\
\hline \multicolumn{2}{|c|}{ Anhingidae } & & & & 36. Shikra & Accipiter badius & $U$ & $\mathrm{R}$ \\
\hline \multirow[t]{3}{*}{7.} & Oriental Darter & Anhinga melanogaster & C & LM & 37. Eurasian Sparrow Hawk & Accipiter nisus & $U$ & M \\
\hline & & & & & 38. Eurasian Marsh Harrier & Circus aeruginosus & C & M \\
\hline & Ardeidae & & & & 39. Pallid Harrier & Circus macrourus & $U$ & M \\
\hline 8. & Grey Heron & Ardea cinerea & C & $\mathrm{R}$ & 40. Pied Harrier & Circus melanoleucos & U & M \\
\hline 9. & Purple Heron & Ardea purpurea & C & $\mathrm{R}$ & 41. Black-shouldered Kite & Elanus caeruleus & $U$ & $\mathrm{R}$ \\
\hline 10. & Pond Heron & Ardeola grayii & C & $\mathrm{R}$ & 42. Brahminy Kite & Haliasturindus & C & $\mathrm{R}$ \\
\hline 11. & Cattle Egret & Bubulcus ibis & $A$ & $\mathrm{R}$ & 43. Black Kite & Milvus migrans & C & $\mathrm{R}$ \\
\hline 12. & GreatEgret & Casmerodius albus & $U$ & $\mathrm{R}$ & 44. Osprey & Pandion haliaetus & $U$ & $\mathrm{R}$ \\
\hline 13. & Black Bittern & Dupetor flavicollis & C & $\mathrm{R}$ & 45. Oriental Honey Buzzard & Pernis ptilorhyncus & $U$ & LM \\
\hline 14. & Little Egret & Egretta garzetta & $A$ & $\mathrm{R}$ & & & & \\
\hline 15. & Western Reef Egret & Egretta gularis & 0 & $\mathrm{R}$ & Phasianidae & & & \\
\hline 16. & Cinnamom Bittern & Ixobrychus cinnamomeus & $U$ & $\mathrm{R}$ & 46. Grey Francolin & Francolinus pondicerianus & $U$ & $\mathrm{R}$ \\
\hline 17. & Yellow Bittern & Ixobrychus sinensis & $U$ & $\mathrm{R}$ & 47. Red Spur Fowl & Galloperdix spadicea & U & $\mathrm{R}$ \\
\hline 18. & Intermediate Egret & Mesophoyx intermedia & $A$ & $\mathrm{R}$ & & & & \\
\hline \multirow[t]{2}{*}{19.} & Black-crowned Night Heron & Nycticorax nycticorax & C & $\mathrm{R}$ & $\underline{\text { Rallidae }}$ & & & \\
\hline & & & & & 48. White-breasted Waterhen & Amaurornis phoenicurus & C & $\mathrm{R}$ \\
\hline \multicolumn{2}{|c|}{$\underline{\text { Ciconiidae }}$} & & & & 49. Common Coot & Fulica atra & U & LM \\
\hline 20. & Asian Openbilled Stork & Anastomus oscitans & C & LM & Common Moorhen & Gallinula chloropus & C & $\mathrm{R}$ \\
\hline 21. & White Stork & Ciconia ciconia & $U$ & M & Purple Swamphen & Porphyrio porphyrio & C & $\mathrm{R}$ \\
\hline 22. & White-necked Stork & Ciconia episcopus & $U$ & $\mathrm{R}$ & 52. Ruddy-breasted Crake & Porzana fusca & C & $\mathrm{R}$ \\
\hline 23. & Black Stork & Ciconia nigra & $U$ & M & & & & \\
\hline \multirow[t]{2}{*}{24.} & Painted Stork & Mycteria leucocephala & 0 & LM & $\underline{\text { Jacanidae }}$ & & & \\
\hline & & & & & 53. Pheasant-tailed Jacana & Hydrophasianus chirurgus & $U$ & LM \\
\hline \multicolumn{2}{|c|}{ Threskiornithidae } & & & & 54. Bronze-winged Jacana & Metopidius indicus & C & $\mathrm{R}$ \\
\hline 25. & Eurasian Spoonbill & Platalea leucorodia & $U$ & LM & & & & \\
\hline \multirow[t]{2}{*}{26.} & Asian White lbis & Threskiornis melanocephalus & C & LM & $\underline{\text { Glareolidae }}$ & & & \\
\hline & & & & & 55. Small Pratincole & Glareola lactea & C & LM \\
\hline
\end{tabular}




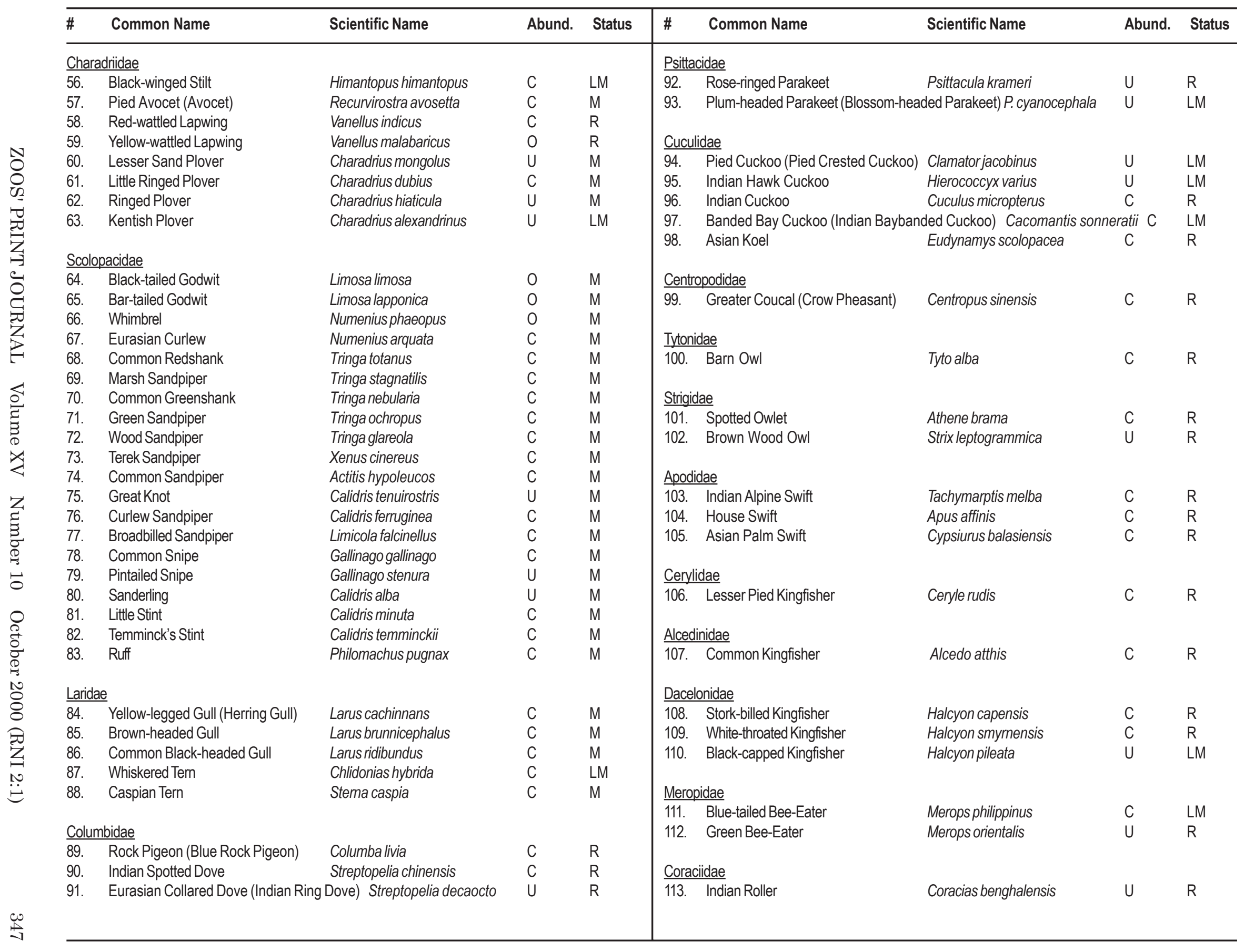




\begin{tabular}{|c|c|c|c|c|c|c|c|c|}
\hline Common Name & Scientific Name & Abund. & Status & $\#$ & Common Name & Scientific Name & Abund. & Status \\
\hline \multicolumn{4}{|c|}{ Megalaimidae } & \multirow{6}{*}{\multicolumn{2}{|c|}{$\begin{array}{ll}\text { 138. } & \text { Pale capped Babbler } \\
\text { 139. } & \text { Common Babbler } \\
\text { 140. } & \text { Jungle Babbler } \\
\text { 141. } & \text { Rufous Babbler }\end{array}$}} & Turdoides affinis & C & $\mathrm{R}$ \\
\hline White-cheeked Barbet & Megalaima viridis & C & $\mathrm{R}$ & & & Turdoides caudatus & 0 & $\mathrm{R}$ \\
\hline & & & & & & Turdoides striatus & C & $\mathrm{R}$ \\
\hline$\underline{\text { Picidae }}$ & \multirow{5}{*}{ Dinopium benghalense } & & & & & Turdoides subrufus & U & $\mathrm{R}$ \\
\hline Black-rumped Flame-backed & & \multirow[t]{4}{*}{ U } & \multirow[t]{3}{*}{$\mathrm{R}$} & & & & & \\
\hline & & & & & & \multicolumn{3}{|c|}{$\underline{\text { Cisticolidae }}$} \\
\hline & & & & 142 & Zitting Cisticola & Cisticola juncidis & C & $\mathrm{R}$ \\
\hline \multicolumn{2}{|c|}{$\underline{\text { Hirundinidae }}$} & & & & Grey-breasted Prinia & Prinia hodgsonii & C & $\mathrm{R}$ \\
\hline Red-rumped Swallow & Hirundo daurica & C & LM & 144 & Plain Prinia & Prinia inornata & C & $\mathrm{R}$ \\
\hline Barn Common Swallow & Hirundo rustica & C & LM & 145 & Ashy Prinia & Prinia socialis & C & $\mathrm{R}$ \\
\hline \multicolumn{4}{|c|}{$\underline{\text { Oriolidae }}$} & \multicolumn{5}{|c|}{ Sylviidae } \\
\hline Eurasian Golden Oriole & Oriolus oriolus & U & LM & 146 & Blyth's Reed Warbler & Acrocephalus dumetorum & U & LM \\
\hline \multirow[t]{2}{*}{ Black-hooded Oriole } & \multirow[t]{2}{*}{ Oriolus xanthornus } & \multirow[t]{2}{*}{$U$} & \multirow[t]{2}{*}{$\mathrm{R}$} & 147 & Clamorous Reed-Warbler & Acrocephalus stentoreus & U & $\mathrm{R}$ \\
\hline & & & & 148 & Common Tailor Bird & Orthotomus sutorius & C & $\mathrm{R}$ \\
\hline White-bellied Drongo & Dicrurus caerulescens & C & $\mathrm{R}$ & \multicolumn{5}{|c|}{ Passeridae } \\
\hline Ashy Drongo & Dicrurus leucophaeus & C & $\mathrm{R}$ & 149 & $\overline{\text { Red Munia }}$ & Amandava amandava & C & $\mathrm{R}$ \\
\hline \multirow[t]{2}{*}{ Black Drongo } & \multirow[t]{3}{*}{ Dicrurus macrocercus } & \multirow[t]{3}{*}{ C } & \multirow[t]{3}{*}{ LM } & 150 & Paddy Field Pipit & Anthus rufulus & C & LM \\
\hline & & & & & Hill Munia & Lonchura kelaarti & U & $\mathrm{R}$ \\
\hline$\underline{\text { Sturnidae }}$ & & & & 152 & Black-headed Munia & Lonchura malacca & $A$ & $\mathrm{R}$ \\
\hline Jungle Myna & Acridotheres fuscus & C & R & 153 & Plain Munia & Lonchura malabarica & C & $\mathrm{R}$ \\
\hline Indian/Common Myna & Acridotheres tristis & C & $\mathrm{R}$ & 154 & Scaly-breasted Munia & Lonchura punctulata & C & $\mathrm{R}$ \\
\hline & & & & 155 & White-rumped Munia & Lonchura striata & $U$ & $\mathrm{R}$ \\
\hline & & & & 156 & Grey Wagtail & Motacilla cinerea & U & M \\
\hline Common lora & Aegithina tiphia & U & $\mathrm{R}$ & 157 & Citrine Wagtail & Motacilla citreola & U & M \\
\hline Ashy Wood Swallow & Artamus fuscus & U & $\mathrm{R}$ & 158 & Yellow Wagtail & Motacilla flava & 0 & LM \\
\hline Jungle Crow & Corvus macrorhynchos & U & $\mathrm{R}$ & 159 & Large Pied Wagtail & Motacilla maderaspatensis & $\mathrm{C}$ & $\mathrm{R}$ \\
\hline House Crow & Corvus splendens & C & R & 160 & Chestnut-shouldered Petronia & Petronia xanthocollis & C & $\mathrm{R}$ \\
\hline Rufous Tree Pie & Dendrocitta vagabunda & C & $\mathrm{R}$ & 161 & Streaked Weaver & Ploceus manyar & C & $\mathrm{R}$ \\
\hline & & & & & Baya Weaver & Ploceus philippinus & $A$ & $\mathrm{R}$ \\
\hline Jerdon's Leafbird & Chloropsis cochinchinensis & C & $\mathrm{R}$ & $\underline{\mathrm{Nec}}$ & iniidae & & & \\
\hline & & & & & Thick-billed Flowerpecker & Dicaeum agile & C & $\mathrm{R}$ \\
\hline notidae & & & & 164 & Tickell's Flowerpecker & Dicaeum erythrorhynchos & C & $\mathrm{R}$ \\
\hline Red-vented Bulbul & Pycnonotus cafer & C & $\mathrm{R}$ & 165 & Purple Sunbird & Nectarinia asiatica & C & $\mathrm{R}$ \\
\hline Red-whiskered Bulbul & Pycnonotus jocosus & U & LM & 166 & Loten's Sunbird & Nectarinia lotenia & U & $\mathrm{R}$ \\
\hline capidae & & & & & Purple-rumped Sunbird & Nectarinia zeylonica & C & $\mathrm{R}$ \\
\hline Oriental Magpie Robin & Copsychus saularis & C & $\mathrm{R}$ & & & & & \\
\hline Desert Wheatear & Oenanthe deserti & 0 & M & & ndance; C- Comn & O- Occasional & & \\
\hline Pied Bushchat & Saxicola caprata & $U$ & $\mathrm{R}$ & & sident; M- Migrant; LM-Local N & nt & & \\
\hline Indian Robin & Saxicoloides fulicata & U & $\mathrm{R}$ & Cor & non names are after Manakadar & (1998) and scientific names a & xonomy aft & er Inskipp \\
\hline Asian Paradise Flycatcher & Terpsiphone paradisi & $U$ & LM & eta & 1996) & & & \\
\hline
\end{tabular}


Research Institute and Kerala Forest Department. 18 pp. (Draft Unpublished).

Anon (1996). Asia-Pacific Waterbird Conservation Strategy, 19962000. Wetlands International Asia-Pacific, Kualalumpur, Publication No.117, and International Waterfowl and Wetlands Research Bureau Japan Committee, Tokyo.

Daniels, R.J.R. (1998). A Field Guide to the Birds of Southwestern India. Oxford University Press, Delhi, 217 pp.

Grimmett, R., C. Inskipp and T. Inskipp (1998). Birds of Indian Subcontinent. Oxford University Press, 888 pp.

Inskipp T., N. Lindsey and W. Duckworth (1996). An annotated checklist of the birds of the oriental region. Oriental Bird Club, U.K. Jairaj, A.P. and V.K. Sanjeeve Kumar (1990). Occurrence of Spoonbill Platalea leucorodia Linn. in Kerala. J. Bombay nat. Hist. Soc. 87(2): 289.

Jayson, E.A. (2000). Occurrence of Black Stork Ciconia nigra (Linnaeus) in Kole wetlands of Thrissur, Kerala. Newsl. Bird Watchers 40(3): 39-40.

Jayson, E.A. and C. Sivaperuman (1999). Kole lands of Thrissur: A threatened wetland ecosystem. Evergreen, Newsletter of Kerala Forest Research Institute, Peechi, (43): 10-11,

Jayson, E.A. and P.S. Easa (2000). Documentation of vertebrate fauna in Mangalavan mangrove area. KFRI Research Report No. 183. Kerala Forest Research Institute, Peechi.

Johnkutty, I. and V.K. Venugopal (1993). Kole wetlands of Kerala. Kerala Agricultural University, Thrissur, 68 pp.

Manakadan, R., J.C. Daniel, A.R. Rahmani, M. Inamdar and G. ugra (1998). Standardized English common names of the birds of the Indian subcontinent - a proposal. Buceros 3(2): 55 pp. Bombay Natural History Society, Mumbai.

Nameer, P.O. (1993). Conservering the Kole Wetlands - a potential Ramsar Site from southern India. In: Verghese, A., S. Sridhar and A.K. Chakravarthy (eds.) Bird conservation strategies for the Nineties and Beyond. Ornithological Society of India, Bangalore pp. 105-110. Nameer, P.O., R. Resmi Nair, K.R. Anoop, S.G. Nair, R. Lekshmi and P. Radhakrishnan (2000). Birds of Kerala Agricultural University Campus, Thrissur. Zoos' Print J. 15(4): 243-246.

Neelakantan, K.K., C. Sasikumar and R. Venugopalan (1993). $A$ Book of Kerala Birds. World Wide Fund for Nature-India, Kerala State Committee, Trivandrum, $146 \mathrm{pp}$.

Perennou, C. (1990). Species to look for in India. Newsl. Bird Watchers 30(5\&6): 10.

Ravindran, P.K. (1993). Occurrence of the Glossy Ibis in Kole wetland, Thrissur District, Kerala. Newsl. Bird Watchers 33(6): 109.

Ravindran, P.K. (1995). The Kole wetlands - an avian paradise in Kerala. Newsl. Bird Watchers 35(1): 2-5.

Ravindran, P.K. (1999). White-necked Stork in Kole wetlands. Newsl. Bird Watchers 39(3): 51.

Santharam, V. (1995). The Grey-throated or Plain Sand Martin Riparia paludicola Vieillot - a new bird for southern India. J. Bombay nat. Hist. Soc. 92(1): 122.

Sivaperuman, C. and E.A. Jayson (In press a). Black-winged Kite Elanus caeruleus vociferous (Latham) preying on Wood Sandpiper Tringa glareola Linnaeus. J. Bombay nat. Hist. Soc.

Sivaperuman, C. and E.A. Jayson (In press b). Occurrence of Northern Shoveller Anas clypeata Linnaeus in Kole Wetlands of Thrissur, Kerala. J. Bombay nat. Hist. Soc.

Woodcock, M.W. (1979). Collins Handguide to the Birds of the Indian Sub-continent, Collins, St. Jame's Place, London. 176 pp.

\section{THE BLACK DRONGO'S (DICRURUS MACROCERCUS (BECHSTEIN)) WHITE CROWN}

\section{G. Prasad}

P.G. Student, College of Forestry, Kerala Agricultural University, Trichur, Kerala 680656, India.

E-mail: gprasadg@rediffmail.com

The Black Drongo (Dicrurus adsimilis (Bechstein)) or the King Crow belongs to the family Dicruridae. It is a common resident bird seen all over India. It inhabits open deciduous forests and cultivated lands.

A Black Drongo was noticed residing near the Kerala Agricultural University campus in October 1999, in a rice field and deserves special mention. The body size and the colour were same as that of other Black Drongos, but the head had a prominent white round patch at the top. The feathers at the top of the head were striking white giving a complete contrast, resembling a crown. The patch did not extend down up to the eyes of the bird. The bird was an adult and the two white spots on the sides of the bill were prominent. The bird was noticed perching on the tip of bushtops, electric cables, and its feeding pattern was same as that of the other Black Drongos. The rice fields provided a feast of insects for the bird. This bird made attempts to chase and attack crows, kites, etc, flying through the locality as other Black Drongos do. This Drongo is resident, according to the local people.

The white patch was seen on the top of the head only, and the rest of the body remained jet black. This cannot be considered as albinism where the whole body becomes white due to the lack of pigment production. There are no previous records of the Drongo's albinism or 'a Black Drongo with a white patch' but in many other birds and animals, albinism has been reported. The present case may be considered as a freak of nature.

Received 24 July 2000 Accepted 20 August 2000 